\title{
한국형 과학기술혁신 \\ ODA 전략 및 실행 방안 ${ }^{1)}$
}

\section{목 차}

I. 들어가는 말

II. 과학기술혁신 $\mathrm{ODA}$ 의 개념

1. OECD DAC에서 본 과학기술혁신 ODA

2. 부가가치사슬에서 본 과학기술혁신 ODA의 개념

III. 한국 및 개도국의 과학기술 발전 특성

1. 한국의 과학기술 발전 특성

2. 개도국의 과학기술 발전 특성

IV. 한국형 과학기술혁신 모델의 이전 개념

V. 과학기술혁신 ODA의 현황 및 문제점

1. ODA 정책 관점

2. 과학기술 ODA 사업 수행 경험 관점

VI. 맺는 말

1) 이 글은 STEPI 주최 2015년 4차 과학기술 ODA 포럼, 혁신클러스터학회 주최 2015년 춘계학술대회, STEPI 및 World Bank 공동 주최 1st conference on Science, Technology, Innovation(STI) and Development 발표 자료를 바탕으로 작성되었다. 발표 과정에서 비판과 토론을 해주신 여러분들에게 감사드린다. 


\section{I. 들어가는 말}

지난 반세기 동안 한국의 경제는 눈부시게 발전하였으며 이는 세계적으로도 유례가 없는 일이다. 이에 따라 일부 개도국에서는 국가 지도자들이 한국을 모델로 삼아 경제발전을 추구하고 있기도 하 다. 한국은 이제 원조를 받는 원조수원국에서 원조를 주는 원조공여국으로 변했으며 우리 정부는 지 속적으로 $\mathrm{ODA}$ 사업의 증가를 통해 국제 사회에 기여하고 있다.

한국의 발전을 설명하는데는 여러 요인이 있겠지만 자원이 많지 않은 나라에서 경제를 발전시킬 수 있었던 것은 무엇보다도 근면한 국민, 높은 교육열, 유능한 정부관료 등 여러 요인이 있었기 때문 이라 하겠다. 또한 그 중에서도 국가의 과학기술혁신 역량을 개발시킴으로써 산업의 발전을 지원한 사실도 중요하다.

한국은 2010 년 $\mathrm{OECD}$ 의 개발협력위원회 $(\mathrm{DAC})^{2)}$ 에 정식으로 가입하였으며 국제적 규범에 따라 원 조활동을 해오고 있다. 그러나 $\mathrm{DAC}$ 의 규범이나 정의를 보면 과학기술혁신 분야가 명시적으로 지정되 어 있지 않고 우선순위가 떨어지는 듯한 인상을 준다. 아마도 이는 과거 사회적 문제, 환경, 기초적인 경제 문제 해결 등을 중요시했던 $\mathrm{ODA}$ 의 속성상 당연한 것인지도 모른다. 그렇지만 현대 사회에 있 어서 과학기술은 우리 사회의 곳곳에 깊숙이 스며있고 또한 산업의 경쟁력을 결정하는 중요한 요인이 다. 이런 이유로 최근 UN을 중심으로 한 지속가능한 개발목표(SDGs)에서도 과학기술이 강조되고 있 다. 그러나 우리나라의 $\mathrm{ODA}$ 를 보면 과학기술혁신이 ODA의 중요한 분야로 규정되어 있지는 않으며 이에 대한 논의도 부족한 실정이다.

본 논문은 기본적으로 정책적 방향을 탐색하는 탐색적 성격의 정책연구이다. 이상과 같은 배경과 목적을 바탕으로 과학기술혁신 $\mathrm{ODA}$ 의 방향을 다음과 같은 의문을 가지고 탐색하고자 한다.

- 과학기술혁신 ODA의 분야는 무엇인가?

- 한국형 과학기술혁신 발전 모델이 있는가? 있다면 그 특성은 무엇인가?

- 개도국의 과학기술혁신의 특성은 무엇인가?

- 한국형 과학기술혁신 발전 모델을 개도국에 전수하는 것이 가능한가?

- 이런 모든 상황을 고려할 때 한국이라는 국가 차원의 과학기술혁신 ODA 전략 및 실행방안은 무 엇인가?

2) 국제사회에서는 이제 원조(aid)가 갖는 일부 부정적 의미를 고려하여 협력(assistance)이라는 용어를 사용한다. 이 런 의미에서 이 글에서도 개발협력위원회라는 용어를 사용한다. 


\section{〈표 1〉 공적원조의 제 분야}

\begin{tabular}{c|l}
\hline 분야 & \multicolumn{1}{c}{ 세부 분야 } \\
\hline $\begin{array}{c}\text { 사회적 } \\
\text { 인프라 · 서비스 }\end{array}$ & 교육, 보건, 인구정책/시책 및 생식보건, 수자원 및 위생, 공공행정 및 시민사회 등 \\
\hline $\begin{array}{c}\text { 경제적 } \\
\text { 인프라 · 서비스 }\end{array}$ & 교통 및 물류, 통신, 에너지 개발 및 공급, 금융 및 재무 서비스 등 \\
\hline 생산부문 & 농업, 임업, 어업, 제조산업, 광물자원 및 광업, 건설, 통상정책 및 규정, 관광 등 \\
\hline 다부문 · 융합부문 & 환경, 기타 교육, 연구기관 및 과학기관 등 \\
\hline 채무관련 부문 & 채무 탕감 등 \\
\hline 물자지원 부문 & 일반 예산 지원, 식량 지원 등 \\
\hline 인도주의적 부문 & 긴급구호, 재난 지원 등 \\
\hline 기타 & 일반 행정비용, 미사용 금액 등 \\
\hline
\end{tabular}

\section{II. 과학기술혁신 ODA의 개념}

\section{1. $\mathrm{OECD} \mathrm{DAC}$ 에서 본 과학기술혁신 ODA}

국가간 공적원조는 여러 분야가 있지만 전통적으로 의식주 등 인간의 기초적 생활 부분, 경제 · 산업 발전 관련 원조, 교육문화적 분야의 원조 등 여러 가지로 분류가능하다. 이에 따라, $\mathrm{DAC}$ 는 $\mathrm{ODA}$ 를 사회인프라, 경제인프라, 생산, 다부문, 채무, 물자지원, 인도주의적 지원 등으로 분류하고 있다.

$\mathrm{OECD}$ 개발협력위원회에서는 따로 분류하지 않았지만 최근 부상하는 분야로 과학기술혁신 분야 를 꼽을 수 있다. 한국의 사례에서 보듯이 과학기술혁신 역량의 유무는 산업발전에 중요한 역할을 한 다. 제조업 부문에서 산업기술 역량이 약한 나라에서 경제를 발전시킨다는 것은 매우 어렵다. 인터넷 등 정보통신 기술은 선진국뿐만 아니라 개도국에서도 각국의 정치문화에 많은 영향을 미친다. 그러나 과학기술혁신 분야는 $\mathrm{DAC}$ 의 분류에서 명확하게 설정되지는 않았다. 이는 과학기술 자체가 여러 부 분에 걸쳐있는 성격을 가지고 있기 때문이기도 하다. 그렇지만 과학기술혁신 분야의 중요성을 고려할 때 이를 독립시켜서 분석하고 정책적 시사점을 찾는 노력은 필요하다고 본다. $\mathrm{DAC}$ 의 정의 중에서 다 음과 같은 분야를 선정하여 과학기술혁신 ODA로 분류하였다(강희종 · 임덕순, 2014). 
〈표 2〉 DAC의 지원 분야 중 과학기술 ODA 해당 분야

\begin{tabular}{|c|c|c|c|}
\hline 지원 분야 & 대분류 & 중소분류 & $\mathrm{CRS}^{3)}$ Code \\
\hline \multirow{5}{*}{ 사회인프라 } & \multirow{3}{*}{ 보건 } & 의료교육 및 훈련 & 12181 \\
\hline & & 의료연구 & 12182 \\
\hline & & 보건인력개발 & 12281 \\
\hline & $\begin{array}{l}\text { 인구정책/시책 및 } \\
\text { 생식보건 }\end{array}$ & $\begin{array}{c}\text { 인구정책 및 생식보건을 } \\
\text { 위한 인력개발 }\end{array}$ & 13081 \\
\hline & 수자원 및 위생 & 식수공급 및 위생 부문교육 & 14081 \\
\hline \multirow{3}{*}{ 경제인프라 } & 교통 & 운송 및 창고부문 교육 & 21081 \\
\hline & \multirow{2}{*}{ 에너지 개발 및 공급 } & 에너지교육/훈련 & 23081 \\
\hline & & 에너지 연구 & 23082 \\
\hline \multirow{18}{*}{ 생산부문 } & \multirow{2}{*}{ 농업 } & 농업관련 교육/훈련 & 31181 \\
\hline & & 농업연구 & 31182 \\
\hline & \multirow{2}{*}{ 임업 } & 임업교유/ᄀ/훈련 & 31281 \\
\hline & & 임업연구 & 31282 \\
\hline & \multirow{2}{*}{ 어업 } & 어업교육/훈련 & 31381 \\
\hline & & 어업연구 & 31382 \\
\hline & \multirow{12}{*}{ 산업 } & 산업개발 & 32120 \\
\hline & & 중소기업개발 & 32130 \\
\hline & & 가내공업 및 수공업 & 32140 \\
\hline & & 농수산물 가공업 & 32161 \\
\hline & & 임산물 가공 & 32162 \\
\hline & & 섬유, 피혁 및 대체소재 & 32163 \\
\hline & & 화공 & 32164 \\
\hline & & 비료공장 & 32165 \\
\hline & & 시멘트/인조대리석/소석회 & 32166 \\
\hline & & 에너지 가공 & 32167 \\
\hline & & 의약품생산 & 32168 \\
\hline & & 철강산업 & 32169 \\
\hline
\end{tabular}


〈표 2〉 DAC의 지원 분야 중 과학기술 ODA 해당 분야 (계속)

\begin{tabular}{|c|c|c|c|}
\hline 지원 분야 & 대분류 & 중소분류 & $\mathrm{CRS}^{3)}$ Code \\
\hline \multirow{4}{*}{ 생산부문 } & \multirow{4}{*}{ 산업 } & 비철금속산업 & 32170 \\
\hline & & 엔지니어링(기계공업) & 32171 \\
\hline & & 운송기계산업 & 32172 \\
\hline & & 기술연구개발 & 32182 \\
\hline \multirow{4}{*}{ 다부문 } & \multirow{4}{*}{ 다부문 } & 환경교육/훈련 & 41081 \\
\hline & & 환경연구 & 41082 \\
\hline & & 다분야 기타교육 & 43081 \\
\hline & & 연구/과학기관 & 43082 \\
\hline
\end{tabular}

출처: 한국수출입은행(2013)의 〈참고자료 2〉 및 CRS 코드를 이용하여 재구성

재인용: 강희종, 임덕순 (2014)

〈표 3〉DAC의 지원 분야 중 ICT ODA 해당 분야

\begin{tabular}{c|c|c|c}
\hline 지원 분야 & 대분류 & 중소분류 & $\mathrm{CRS}^{3)}$ Code \\
\hline \multirow{3}{*}{ 경제인프라 } & \multirow{3}{*}{ 통신 } & 통신/전화 & 22020 \\
\cline { 3 - 4 } & & 라디오/텔레비전/인쇄매체 & 22030 \\
\cline { 3 - 4 } & & 정보통신기술 & 22040 \\
\hline
\end{tabular}

출처: 한국수출입은행(2013)의 〈참고자료 2〉 및 CRS 코드를 이용하여 재구성

재인용: 강희종, 임덕순 (2014)

- 과학기술 $\mathrm{ODA}$ : 교육 및 훈련, 연구개발, 인력개발 등 $\mathrm{DAC}$ 지원 분야 중 과학기술과 관련된 $\mathrm{ODA}$ 로서, 〈표 2〉에 해당하는 분야

- ICT ODA: 방송, 통신 등 DAC 지원 분야 중 정보통신기술과 관련된 ODA로서, 〈표 3〉에 해당 하는 분야

3) CRS: Creditor Reporting System 


\section{2. 부가가치사슬에서 본 과학기술혁신 ODA의 개념}

이상에서 살펴본 개념이 기존 $\mathrm{ODA}$ 분야를 재구성해서 본 것이라면 실제 $\mathrm{ODA}$ 사업을 추진하는 관 점에서는 과학기술혁신 ODA를 다음과 같이 볼 수 있다. 즉, 기술혁신 프로세스를 부가가치 사슬 관 점에서 분류하고 각 프로세스별로 과학기술 $\mathrm{ODA}$ 를 정의할 수 있다. 흔히들 과학기술혁신 $\mathrm{ODA}$ 를 적 정기술을 지원하는 정도로 알고 있는 경향이 있는데 국가발전 및 산업기술 강화라는 측면에서 보면 과학기술지식을 생산하고 이전하며 이를 활용하는 전 과정이 포함된다. 또한 개도국의 입장에서 보면 이런 과학기술지식을 선진국으로부터 잘 이전받고 활용하는 능력을 확보하는 것까지 포함된다.

과학기술혁신을 가능케 하는 지원 · 인프라 측면에서 보면 개도국이 필요로 하는 것이 과학기술 그 자체 이 외에도 과학기술 정책 역량 강화, 과학기술인력을 배출하는 과학기술 교육기관 설립 · 운영, 과학기술단지 설립 · 운영, 기술금융의 강화 등 실로 여러 부분에서 과학기술혁신 ODA가 가능하다. 즉 과학기술혁신 프로세스 전체와 관련된 부분과 이를 지원하는 소프트 - 하드 인프라 모두에서 가능 하다(임덕순, 2015a).

\section{〈그림 1〉 기술혁신 프로세스}

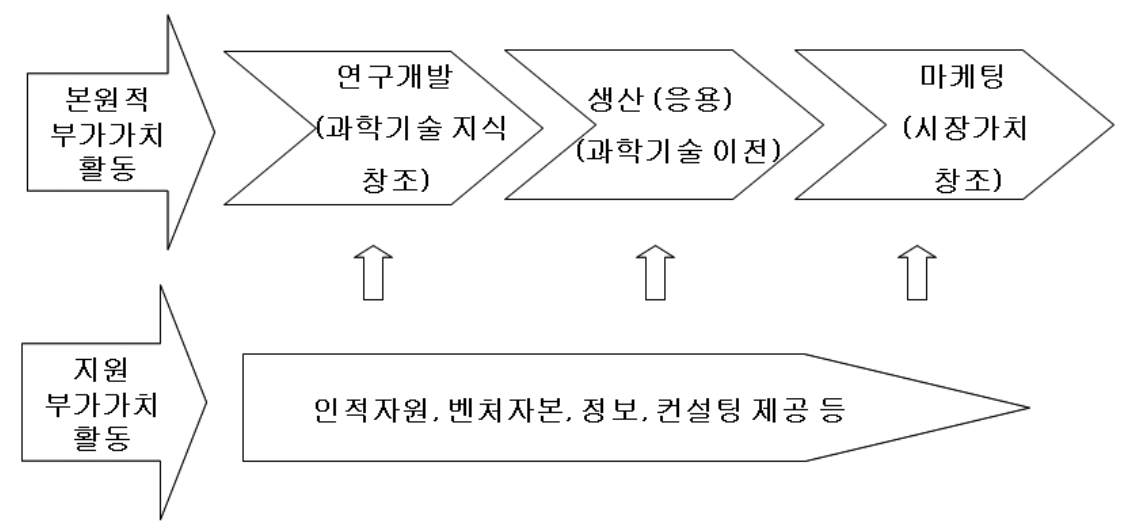

출처: 임덕순(2002)

과학기술혁신의 $\mathrm{ODA}$ 를 세부적으로 분류하면 〈표 4〉와 같다. 대분류로는 국가 차원에서 과학기술 역량을 증가시키기 위한 분야로 전통적인 과학기술 정책 및 이의 집행과 관련된 분야이다. 개도국 정 부는 연구인력 육성, 연구개발 프로그램 실행 등 모든 면에서 부족하며 이는 과기대학, 연구기관, 과 기단지 등 인프라 조성과 함께 해결되어야 하는 사항들이다. 
둘째 주제는 산업기술과 관련된 내용이다. 대부분의 개도국에서 산업기술 역량이 취약한데 특히 노동집약적이고 진입이 비교적 용이한 섬유, 식품가공 등의 분야는 개도국 내부 자원을 활용할 수 있 고 수출 증가 수입대체 효과가 있어 대부분 필요로 하는 분야이다. 또한 IT 등의 분야는 전세계적인 현상으로서 기술 개발보다 기술도입 및 응용 분야에서 요구가 많은 편이다. 이와 더불어 개도국이 가 지고 있는 자연을 활용한 신재생에너지, 환경 분야 등에 대한 기술역량 강화도 시급한 분야이다.

셋째 분야는 사회적 수요에 부응하는 과학기술혁신이다. 동 분야로는 보건, 물, 교육, 문화 등이 있 으며 이 외에도 개도국 정부의 행정효율을 증가시킬 수 있는 전자정부행정시스템 등도 포함된다. 이 분야는 소위 말하는 적정기술 분야가 많이 적용될 수 있지만 반드시 그렇지 만은 않다.

〈표 4〉 과학기술혁신 ODA의 개념적 분류

\begin{tabular}{c|l}
\hline 주제 & \multicolumn{1}{c}{ 세부 분야 } \\
\hline & - 과학기술혁신 정책 \\
국가과학기술 발전 부문 & - 국가연구개발 프로그램 \\
& - 기술이전 · 사업화 \\
& - 과학기술혁신 인프라(과기대학, 과기단지, 공공연구기관 설립 등) \\
\hline 산업지원형 과학기술혁신 & - 개별 산업기술 역량 개발 지원(IT, 섬유, 식품가공, 농업, 환경, 에너지 등) \\
\hline 사회발전 지원형 & - 행정시스템, 보건, 물, 교육, 문화 등 \\
과학기술혁신 &
\end{tabular}

출처: 임덕순 (2015a, 2015b)

\section{III. 한국 및 개도국의 과학기술 발전 특성}

\section{1. 한국의 과학기술 발전 특성}

한국은 불과 반세기 만에 매우 높은 경제성장을 이룬 나라로서 개도국들이 참고하는 중요한 나라 가 되었다. 한국의 발전을 설명하는 여러 이론이 있고 학자마다 다양한 의견이 있지만 효과적인 정부 정책, 근면한 국민, 높은 교육열 등 공통적으로 꼽는 요인들이 있다. 한편 한국은 발전 초창기부터 과 학기술의 중요성을 강조하고 과학기술을 통해서 산업 경쟁력을 강화해온 점에서 독특한 점이 있다.

한국의 과학기술 발전상의 특성은 무엇인가? 이런 특성들을 잘 분석하면 한국형 과학기술발전 모 델에 대한 개념을 도출할 수 있다. 이 글에서는 목적이 한국의 과학기술 발전 모델 전체를 분석하는 것은 아니기 때문에 개도국의 과학기술 발전 현황과 대비되는 점을 중심으로 혁신 주체와 정책 방향 
이라는 점에서 살펴본다. 우선 혁신 주체를 보면 한국은 정부의 역할이 매우 중요했으나 시간이 지남 에 따라 조금씩 감소하는 형태이다. 경제 발전과 더불어 기업이 기술혁신에서 차지하는 비중이 높아 졌고 정부의 역할을 상대적으로 감소하기 시작하였다. 이는 정부의 연구개발투자가 지속적으로 증가 했음에도 불구하고 산업의 역할이 상대적으로 더 빨리 증가했기 때문이다.

〈표 5〉 한국과학기술 발전의 특성: 혁신주체

\begin{tabular}{|c|c|c|c|}
\hline 혁신주체 & 1970 80 & 1990 2010 & $2010 \sim$ \\
\hline 정부 & 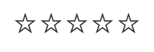 & 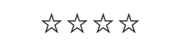 & 论弥论 \\
\hline 산업계 & 诸 & 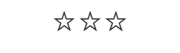 & 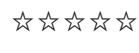 \\
\hline 대학 & 论 & 论坛场 & 论弥弥 \\
\hline 정부공공연구기관 & 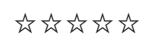 & 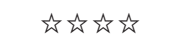 & 计坛㑔 \\
\hline 진흥기관 & 幽 & 头论 & 计坛㑔 \\
\hline 금융기관 & 幽 & 柁 & 论㑔 \\
\hline 지방정부 & 幽 & 计放方 & 论放放 \\
\hline
\end{tabular}

출처: Deok Soon Yim (2015) 일부 수정

과거 한국의 과학기술은 선진국으로부터 빨리 배우고 이를 한국적 상황에 적용시켜 산업의 경쟁력 을 강화하는 것이었다. 그런데 이제 정부는 산업을 중장기적으로 지원할 수 있는 원천기술, 기초과학 등으로 투자 초점을 옮겨가고 있다. 또한 제조업 중심의 산업구조를 과학기술지식과 서비스 등이 결 합된 창조경제형 산업구조로 전환을 꾀하고 있다.

〈표 6〉 한국과학기술 발전의 특성: 정책

\begin{tabular}{c|c|c}
\hline 정책 내용 & $\sim$ 로부터 & $\sim$ 로 \\
\hline 정책 기조 & 추격형 \\
\hline 산업의 중심 & 제조업 & 서비스/창조경제 \\
\hline 국가혁신시스템 & 개별 요소 강화 정책 & 시스템 역량 강화 정책 \\
\hline 지역혁신 & 낮은 수준의 지원 & 높은 수준의 지원 \\
\hline
\end{tabular}

출처: Deok Soon Yim (2015) 


\section{2. 개도국의 과학기술 발전 특성}

모든 개도국의 과학기술 특성을 일반화하는 것은 일반화의 오류가 있을 수 있다. 경제적 상황이 어 려운 최빈국부터 어느 정도 발전을 이미 시작하고 있는 나라도 있기 때문에 일반화하기는 어렵지만 다음과 같은 특성들을 공통적으로 가지고 있음은 사실이다.

첫째, 산업계의 기술에 대한 수요가 매우 낮다. 많은 기업들이 현재의 기술적 역량에 만족하고 생 산성 향상 내지는 신제품 개발을 위한 기술의 필요성을 제대로 인식하지 못한다. 기술적 필요를 느낄 만한 정부공기업 또는 일부 민간 대기업의 경우에도 시장 자체가 독점적인 경우가 많아, 혁신의 필요 성을 상대적으로 덜 느끼는 편이다.

둘째, 과학기술혁신 자원 자체가 매우 부족하다. 과학기술인력, 과학기술투자 등 모든 면에서 자원 이 부족하다. 과학기술은 중장기적으로 투자해야 할 필요가 있는데 과학기술에 대한 투자도 부족하고 연구개발 및 기술사업화를 실행할 인력도 부족하여 매우 어려운 상황이다. 한편 대학, 연구기관, 과학 기술단지 등 과학기술 기반 자체가 부족한 편이다. 일부 개도국의 경우 식민지 시대부터 있었던 대학 이나 연구기관이 있긴 하지만 시설 장비 등이 매우 열악한 편이다.

셋째, 과학기술혁신에 대한 인식이 낮은 편이다. 정부에서는 '당장 급한 곳에 써야될 자원이 부족 한데 과학기술혁신에 언제 투자하는가라는 인식이 있다. 국민들도 마찬가지로 대부분 과학기술에 대 한 절실한 필요를 느끼지 못한다.

넷째, 정부 정책을 보면 여전히 공급 위주의 방향성을 가지고 있고 과학을 강조하는 경향이 있다. 실제로 개도국에서 필요한 것은 생활에 필요한 기술이나 산업이 발전하기 위한 기존 응용기술이 대분 인데 수준 높은 과학에 관심을 기울이는 경우가 많다. 가뜩이나 부족한 과학기술 자원을 과학에 집중 하는 것은 바람직하지 않다.

다섯째, 비단 과학기술 부문에만 국한된 것은 아니지만 개도국 정부의 정책 역량이 많이 떨어진다. 많은 개도국에서 과학기술혁신 정책은 Vision 2020 등 국가 거시 정책적 방향에 언급이 되어 있는 경 우가 많다. 그런데 과학기술혁신이 중요하다는 선언문 정도의 수준이지 어떤 부분을 어떻게 발전시키 겠다는 구체적인 정책이 없는 경우가 대부분이다. 과학기술정책을 실행하고 이를 평가 환류시키는 정 책 메커니즘도 부족하다. 이는 여러 가지 이유가 있지만 기본적으로는 개도국 과학기술 담당 공무원 의 정책역량이 부족하기 때문이다. 
〈표 7〉 개도국 과학기술 현황 및 문제점

\begin{tabular}{l|l}
\hline \multicolumn{1}{c|}{ 항목 } & \multicolumn{1}{c}{ 현황 및 문제점 } \\
\hline 산업 & 기술에 대한 낮은 수요, 낮은 자체 기술역량 \\
\hline 정부 & 정부 정책 역량 결여, 과학위주, 공급위주의 정책 \\
\hline 과학기술 인프라 & 대학, 연구기관, 과학기술 단지 등 낮은 수준의 과학기술 기반 \\
\hline 과학기술 자원 & 연구인력의 부족, 인력 유출, 과학기술 투자 부족 \\
\hline
\end{tabular}

출처: Deok Soon Yim (2015) 내용을 수정

여섯째, 개도국에 젊은 인구가 많다는 점은 앞으로 과학기술을 발전시키기 위한 유리한 조건이다. 과학기술 자체에는 국경이 없고 또 개도국 젊은이들은 이공계 기피 현상도 없는 편이다. 물론 상당수 의 젊은이들이 외국으로 유학 후 돌아오지 않는 현상이 있는 것도 사실이다. 그러나 길게 본다면 개도 국의 경제가 발전하고 풍부한 인력이 있다는 사실은 앞으로 기회도 많다는 점을 시사한다.

\section{IV. 한국형 과학기술혁신 모델의 이전 개념}

한국형 과학기술혁신 모델이 과연 개도국으로 이전가능한지는 가능하다면 어떻게 해야 할지는 두 가지 관점에서 살펴보기로 한다. 첫째 개념적 수준에서의 접근이다. 한국의 국가혁신시스템 발전 과 정에서 경험했던 한국의 특성들이 개도국의 국가혁신시스템 발전 과정에 그대로 적용될 수 있는가 하 는 문제이다. 둘째 접근은 현재 한국의 과학기술관련 ODA 현황을 분석해보고 이를 바탕으로 한국형 과학기술혁신 발전 모델의 이전 전략 내지는 방향성을 분석해본다.

전술하였듯이 개념적으로 보면 한국의 과학기술 발전에는 여러 특성이 있다. 정부가 의지를 가지 고 과학기술에 대한 투자를 하고 정책도 처음에는 응용기술 위주로 시작한 점, 산업이 발전하면서 기 업도 연구개발 투자를 늘린 점 등 여러 특성들이 보인다.

한국형 모델을 이전하는 데는 두 가지 변수가 있다. 첫째, 글로벌 환경의 변화이다. 글로벌화가 진 전됨에 따라 연구인력, 과학기술 자원의 유동성도 증가했다. 그리고 인터넷으로 대표되는 정보통신 기술의 발달로 인해 과학기술 지식에 대한 접근이 상대적으로 쉬워졌다. 게다가 거대 다국적기업의 출현으로 개도국 자체의 기술에 대한 영향이 높아지고 있다. 대부분의 다국적기업은 개도국에 기술을 이전하기보다 기존의 기술만을 가지고 독점적 시장 상황을 유지하려는 경향이 있다. 이에 따라 개도 국의 기술 발전을 저해하기도 한다. 


\section{〈그림 2〉 한국의 국가혁신시스템 발전 모델 이전 개념}

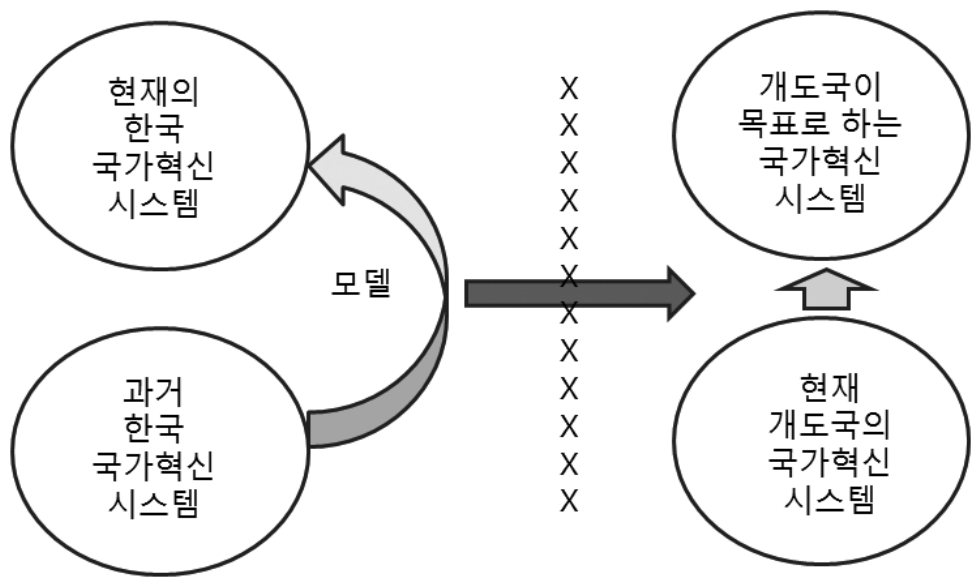

출처: Deok Soon Yim (2015)

둘째, 과거 한국의 상황과 현재 개도국의 상황이 다르다는 점이다. 과거 한국은 단일민족에 전쟁을 겪고 난 상황에서 국가적으로 강력하게 자원 동원과 자원 배분이 가능했던 시스템이었다. 또한 교육 열도 매우 높은 국가였다. 그러나 현재 이런 똑같은 상황을 갖춘 개도국은 찾기 힘들다.

셋째, 한국적 경험을 전수하고 개도국이 이를 받고자 하더라도 과학기술혁신이 가지는 복잡성, 중 장기적 성격, 주고 받는 자의 역량 차이에 따른 장애 등 여러 요인이 있다. 이런 문제는 다음 과학기술 혁신 $\mathrm{ODA}$ 의 현황 및 문제점 차원에서 더 깊이 분석한다.

\section{V. 과학기술혁신 ODA의 현황 및 문제점}

과학기술혁신의 $\mathrm{ODA}$ 의 현황 및 문제점은 여러 측면에서 볼 수 있는데 크게 두 가지 관점에서 접 근 가능하다. 첫째는 $\mathrm{ODA}$ 정책 내지는 방향성의 관점에서, 둘째는 현재 한국의 과학기술 ODA 사업 수행 경험 관점에서 볼 수 있다. 


\section{1. $\mathrm{ODA}$ 정책 관점}

$\mathrm{ODA}$ 정책 관점에서 보면 우선 과학기술혁신 ODA가 무엇인지 왜 해야 하는지에 대한 정책적 공감 이 형성되어 있지 않다는 점이다. $\mathrm{OECD}$ 의 정의 및 국내 $\mathrm{ODA}$ 사업을 보더라도 이런 내용이 명확히 정 의되어 있지 않다. 다만 최근 UN을 중심으로 논의되고 있는 지속가능한 개발 목표(SDGs)에서 기술역 량을 강조하고 있는 것은 국제사회의 논의가 기술 역량과 $\mathrm{ODA}$ 의 접점을 찾아가는 과정으로 보인다.

강희종 · 임덕순(2014)이 한국, 미국, 일본, 독일, 프랑스, 영국 등에 국한해서 OECD DAC 자료 ${ }^{4)}$ 를 분석한 내용에 따르면, 전체 ODA 중 비중을 보면 과학기술이 $3.4 \%$, ICT가 $0.3 \%$ 수준이다. 두 비 중 모두 증가 중이긴 하지만 전체적인 비중은 크지는 않다(2012년 기준). 한국은 과학기술 분야 ODA 비중이 2008년 4.5\%로 최고치를 기록했으나 2012년에는 $2.5 \%$ 로 감소하였다. 한국은 세계 추세와 달 리 ICT ODA 비중이 과학기술 ODA 비중보다 높게 나타나고 있는데 이는 한국의 ICT 발전 추세와도 관련이 깊은 것으로 보인다. ICT 분야는 2009년 9.7\%로 최고치를 기록하였으나 2012년 3.6\%로 감 소 추세를 보이고 있다. 전반적으로 볼 때 과학기술 및 ICT ODA 비중이 2008 2009년 최고치를 기 록했다가 점차 감소하여 다른 나라들과 유사한 정도로 감소하였다.

\section{〈그림 3〉 한국의 원조 분야별 ODA 비중 추이}

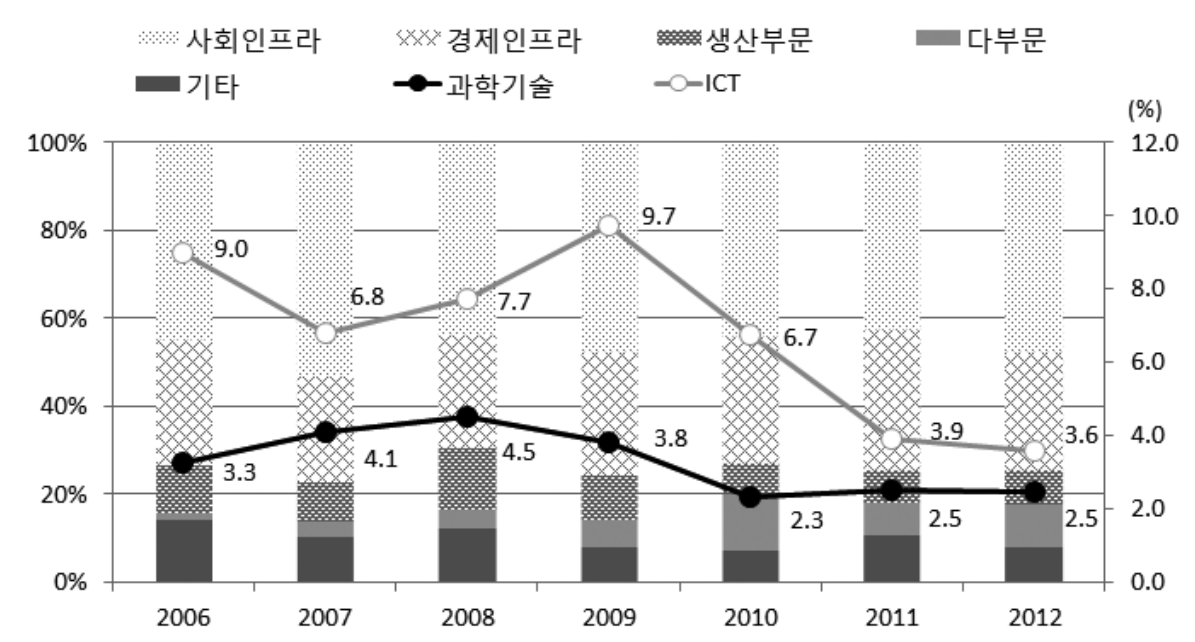

주: 원조 분야별 ODA는 왼쪽 축, 과학기술 - ICT ODA는 오른쪽 축 기준

출처: OECD DAC QWIDS DB 가공 (2014.3)

재인용: 강희종, 임덕순 (2014)

4) http://stats.oecd.org/qwids/ 
우리나라의 대외원조 중심 창구인 한국국제협력단(KOICA)의 사업 분야를 보면 과학기술 분야는 따로 부각되고 있지 않다. 다만 $\mathrm{KOICA}$ 조직에 기술총괄팀을 구성하여 과학기술혁신 분야를 총괄적 으로 접근하고 있는 것은 $\mathrm{ODA}$ 사업 전략에 있어서 획기적인 일이라고 생각된다. 우리나라의 과학기 술혁신 분야 ODA는 KOICA 사업이외에도 국가 연구개발 사업에서 추진되기도 한다. 예를 들어 미래 부에서는 IAEA 기술협력 부담금, 개도국 과학기술지원 사업 등을 추진하며, UN 기구 등을 통해 지원 하는 개도국 과학 부담금도 있다. 이외에도 여러 부처에서 하는 사업 중에 실질적으로는 과학기술 분 야로 분류되는 내용도 있지만 정확한 통계를 얻기가 어렵다.

〈표 8〉 KOICA 사업 분야

\begin{tabular}{l|l}
\hline \multicolumn{1}{c|}{ 분야 } & \multicolumn{1}{c}{ 목적 및 내용 } \\
\hline 교육 & 경제성장 및 빈곤퇴치의 기본 조건 강화 \\
\hline 보건의료 & 아동 및 모성사망률 감소, HIV/AIDS 및 전염병 퇴치 \\
\hline 공공행정 & 정부 책임성 배양 및 거버넌스 강화 \\
\hline 농림수산 & 농림수산업 생산성 향상과 농촌지역 주민 삶의 질 개선 \\
\hline 산업에너지 & 사회간접시설 확충을 통한 자립 가능한 발전 지원 \\
\hline 범분야 & 환경, 성평등, ICT, 인권 \\
\hline 기후변화 대응 분야 & 기후변화 적응능력 강화와 온실가스 감축 \\
\hline
\end{tabular}

출처: KOICA 홈페이지(www.koica.go.kr)

\section{2. 과학기술 ODA 사업 수행 경험 관점}

과학기술혁신은 연구개발에서 시작하여 기술사업화 그리고 최종적으로 부가가치 창출이라는 혁신 에 이르는 복잡한 과정을 거치게 된다. 또한 이런 과정에서 관여하는 주체들이 매우 많게 된다. 과학 기술혁신 ODA와 관련된 주체들은 산학연관이 대표적으로 한국 및 상대 개도국 모두에 존재한다. 또 한 중간에 국제기구 및 국제적 개발은행들이 관여하게 되기도 한다. 주요 내용은 행위자가 산학연관 으로 다양하며 협력의 대상이 과학기술이기 때문에 과학기술 ODA는 다른 ODA와는 매우 다른 복잡 한 속성을 가지게 된다. 


\section{〈그림 4〉 국제과학기술협력 시스템의 구성요소 및 활동}
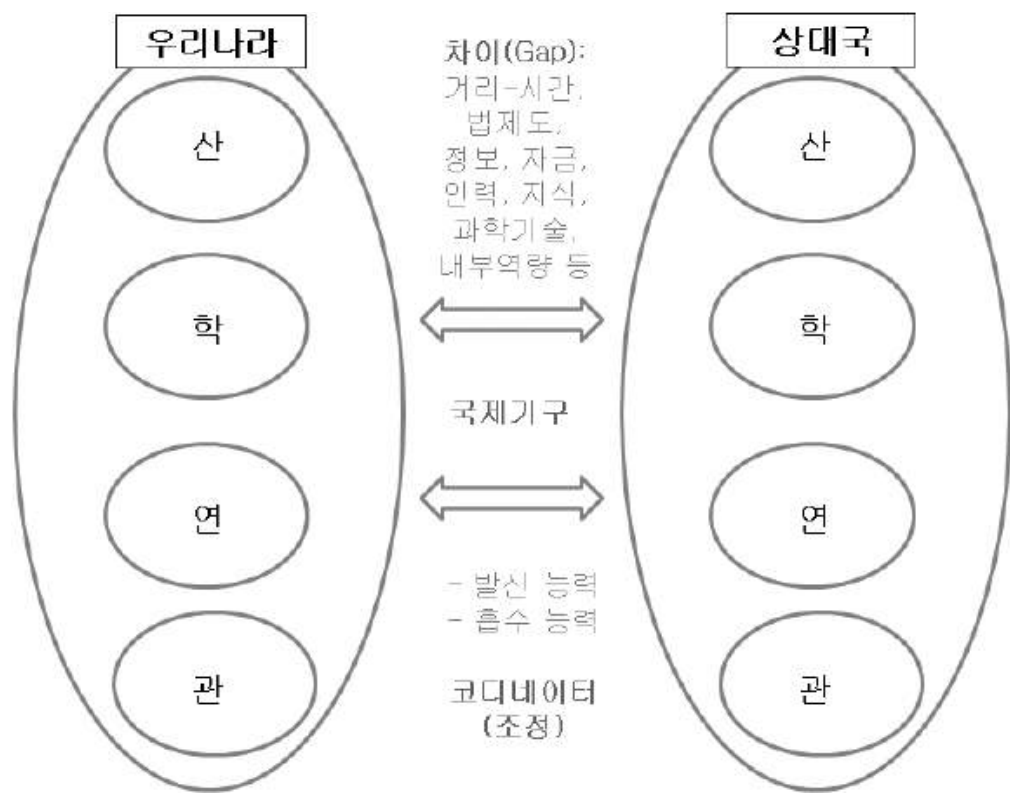

출처: 임덕순(2010), 경기북부 지역혁신기관협의회 통합 Workshop 자료 일부 수정 재인용: 임덕순 (2014)

실제 과학기술관련 ODA 사업 추진에서 발생하는 문제는 시스템 차원에서 볼 수 있다. 첫째는 협 력 주체들의 목표, 문화, 행동양식 등이 다른데서 여러 어려움이 있다. 예를 들어, 개도국 정부는 산업 에 필요한 생산기술을 지원받고 싶지만 정작 대학이나 공공연구기관에서는 세계적으로 유행하는 과학 분야에서 협력을 원하기도 한다. 이런 사례에서 보듯, 정부와 대학, 기업들이 서로 다르지만 ODA 사 업을 매개로 연결되기 때문에 모두가 만족할만한 공통의 목표와 인센티브가 있는 사업을 기획하는 것 이 중요하다.

둘째, 과학기술혁신은 그 자체가 매우 복잡하고 중장기적인 경향이 있다. 이공계 인력을 육성하고 육성된 인력이 연구 - 산업 현장에서 성과를 내기까지는 최소 10 년 이상의 시간이 걸린다. 뿐만 아니 라 해당국의 산업 여건도 기술혁신에 많은 영향을 미친다. 이런 점에서 과학기술 ODA 사업은 지속적 인 관리가 필요하고 성과의 측정도 어려운 측면이 있다.

셋째, 국내에 과학기술혁신관련 ODA 사업 전문가가 많지 않다. 퇴직한 과학기술자 혹은 선교 등 의 목적도 동시에 가진 과학기술자 들은 비교적 수가 많다. 그러나 이런 분들이 ODA 사업이 가지는 사업 전문성을 가지고 있는 경우는 많지 않다. 개도국 사람들의 문화와 정서, 언어, 종교적 차이에 대 
한 폭넓은 이해 뿐 아니라 개도국 정부나 원조 담당 기관, 조직 들을 잘 관리할 수 있는 역량이 필요하 나 그렇지 못한 것이 사실이다.

넷째, 국내에서 과학기술 ODA 사업을 수행하는 조직인 대학, 연구기관 등에서 이런 ODA 사업을 지원하는 행정시스템도 미비한 편이다. 개도국에서 사업을 수행하다 보면 선진국과는 달리 보이지 않 는 비용과 시간상의 지연이 많이 발생한다. 그러나 우리나라의 공공 조직에서는 이런 것에 대한 고려 보다는 행정위주로 관리를 하는 경향이 있어서 많은 문제점이 있다. 한편 국내 원조기관의 사업 추진 방식에 있어서도 과학기술이 갖는 고유한 특성을 잘 다루고 있지 못하다. 과학기술혁신 ODA 사업을 건축이나 보건 사업과 같은 평가 기준을 적용하는 경향이 있다. 과학기술 ODA 사업은 대부분 하드 부분과 소프트 부분이 동시에 있는 경우가 많다. 해당 분야의 과학기술도 잘 알지만 개도국에서 과학 기술 ODA가 어떤 결과를 가져올지에 대한 전체적인 시각을 가지고 평가를 할 수 있어야 한다.

제I장

\section{VI. 맺는 말}

본 연구는 탐색적 연구로서 한국의 과학기술 발전 경험 모델이 있는지 있다면 개도국에 이전될 수 있는지 이전해야 한다면 어떻게 할지를 다양한 각도에서 살펴보았다. 이를 위해 한국의 과학기술 발 전 특성의 개도국과 비교하여 제시하였으며 과학기술혁신 ODA 개념과 그 현황 및 문제점도 분석하 였다.

한국의 과학기술 발전 과정에는 독특한 점들이 많다. 실용적인 정부 정책, 높은 교육열, 과학기술 인프라 조성 등이 독특한 점이며 과학기술 발전은 경제성장의 밑바탕이 되었다. 한국의 과학기술 발 전 경험을 모델화하여 일반화하기에는 아직 더 연구가 필요하다고 본다. 그러나 적어도 이런 특성들 은 다른 나라들과 다른 것으로 한국형 모델로 제시할 수 있을 것이다. 한국형 과학기술 발전 모델이 개도국에 이전된다면 개도국의 산업 발전에 많은 기여를 할 것이다.

과학기술혁신 분야의 ODA 현황을 보면 개념적으로 정리가 제대로 되어 있지 않고 정책적인 고려 도 아직은 높지 않다. 국내 과학기술혁신 관련 ODA 사업을 지원하는 한국과 지원받는 개도국이라는 관점에서 그 동안 사업 경험 및 다른 사업을 관찰한 결과를 바탕으로 기술하였다. 결론적으로 보자면 관련 전문가의 부족, 행정지원 시스템의 미비 등 여러 가지 점이 애로 사항으로 지적되었다.

과학기술혁신 분야는 이제 지속가능한개발목표(SDGs)에서도 하나의 중요한 주제로 등장하고 있 다. 현대는 과학기술이 경제뿐만 아니라 우리의 삶 곳곳에 영향을 미치는 시대이다. 개도국의 현재 여 건이 한국의 발전 시기 상황과는 많이 다르지만 우리의 과거 경험을 새롭게 해석하여 과학기술혁신 
$\mathrm{ODA}$ 를 한다면 개도국의 발전에 많은 도움을 줄 것이다. 한국이 과학기술혁신 $\mathrm{ODA}$ 분야에서 활약할 수 있는 분야는 매우 많다. 선진국의 발전된 과학기술시스템을 바로 개도국에 적용하기는 어렵다. 이 에 비해 한국은 여전히 개도국을 이해할 수 있는 인력들이 많다. 또 한국의 과학기술은 개도국에 적용 하기가 용이한 편이다.

마지막으로 과학기술혁신 ODA 분야에서 다음과 같이 제안하고자 한다. 개도국의 과학기술혁신 수요는 개별 과학기술에도 있지만 자체적으로 과학기술혁신 정책을 수립하고 이를 집행할 수 있는 분야에도 있다. 개별 과학기술의 단순 이전보다는 우리의 과학기술정책 수립 경험에 기반한 자문, 기술경영 인력 육성 프로그램 등이 개도국에 더 많은 도움을 줄 것으로 기대되며 이에 대한 고려가 필요하다.

둘째, 과학기술단지, 과기특성화대학, 공공연구소 설립 등 시스템형, 플랫폼형 사업을 추구하는 것 이 바람직하다. 이런 플랫폼은 한번 완성되면 지속적으로 한국과의 협력을 가능케 함으로써 그 효과 는 지속되는 경향이 있기 때문이다. 따라서 마스터플랜 수립 단계에서부터 한국의 ODA 사업이 추진 된다면 비용대비 효과는 매우 높을 것이다. 


\section{〈참고문헌〉}

Deok Soon Yim. 2015. “Can Korean STI Development Model be transferred to developing countries?”. 1st International Conference on Science, Technology, Innovation and Development, organized by STEPI and World Bank

강희종, 임덕순. 2014. “과학기술· ICT ODA 현황 및 정책방향”. STEPI Insight. 제145호 (2014.7.1). 서울: 과학기술정책연구원

임덕순. 2002. “인도소프트웨어 산업의 혁신클러스터 형성 과정: 개발인가, 진화인가?”. 『기 술혁신학회지」. 제 5 권 제 2 호. 서울: 기술혁신학회

2010. “클러스터 형성을 통한 산학연 협력 방안". 경기북부 지역혁신기관협의회 통 합 Workshop 발표자료, 수원: 경기과학기술진흥원

. 2014. "개도국 과학기술협력의 이슈와 대응” 『2014년 과학기술정책지』. 제 24 권 제 1 호 (통권 제194호). 서울: 과학기술정책연구원

a. 2015. "개도국과 한국의 과학기술 발전경험 공유-혁신클러스터를 중심으로, (Sharing Korea's Science and Technology Experience with Developing Countries: Innovation Clusters". 201년 혁신클러스터학회 춘계학술대회. 대전: 혁신클러스터학회

b. 2015. "한국형 과학기술 ODA 모델 가능한가-In search of Korean STI ODA model”. 제 4차 과학기술 ODA 포럼. 성남시 $\mathrm{KOICA}$ 회의실. 과학기술정책연구원 